\title{
Tuetun keikkatyön malli osallisuutta ja toimijuutta tukemassa
}

Niina Pietilä

\section{TIIVISTELMÄ}

— Tässä käytäntökuvauksessa kuvataan Puuttuva pala -hankkeessa kehitettyä Tuetun keikkatyön mallia. Mallin tavoitteena on luoda tuetun työllistymisen ja avoimien työmarkkinoiden välille sijoittuva työllistymisen mahdollisuus. Osatyökykyisen, työkeikalle haluavan on mahdollista saada tukea prosessin alusta alkaen kokonaistilanteensa ja esimerkiksi vahvuuksiensa, toiveidensa ja pelkojensa pohtimiseen sekä sopivan työkeikan etsimiseen. Tarvittaessa tuki jatkuu myös työkeikan aikana ja sen jälkeen. Onnistuneen keikkatyökokemuksen myötä kokemus omasta osaamisesta, mahdollisuuksista ja johonkin kuulumisesta lisääntyy. Mallissa toimijuuden tukemisen lähtökohtana ovat yksilön tarpeet ja toiveet ilman pakottavaa toimijuutta. Samalla tavoitellaan sosiaalista kasvua ja hyvinvointia.

Avainsanat: osatyökykyinen, keikkatyö, osallisuus, toimijuus 


\section{ABSTRACT}

\section{SUPPORTED SHORT-TERM JOB MODEL SUPPORTS SOCIAL INCLUSION AND AGENCY}

- The review describes the Supported short-term job model developed in the Missing Piece project. The aim of the model is to build an employment opportunity between subsidized employment and the open labor market. Person who wants to do short-term job is able to get support to reflect their overall situation and strengths, wishes and fears. The necessary support will continue during and after the short-term job. Successful experience from the short-term job increases the experience of your own skills, opportunities and belonging to something. In the model, the starting point for supporting agency is the needs and aspirations of the individual for the social growth and well-being sought without coercive agency.

Keywords: person with partial work ability, short-term job, participation, agency

\section{Johdanto}

D erustuslaki takaa jokaiselle oikeuden hankkia elanto työllä, ammatilla ja elinkeinolla, jonka hän on itse valinnut. Tästä huolimatta oikeus ei jokaisen kohdalla toteudu. Esimerkiksi osatyökykyisille oikeus työhön ei ole itsestäänselvyys vaan vaatii toteutuakseen oman motivaation lisäksi myös yhteiskunnallisia tekoja. Hallituksen Osatyökykyisille tie työelämään -kärkihanke oli yksi tällaisista toimista, joiden avulla osatyökykyisten työllisyysaste nousi ja asenteet osatyökyisten työskentelyä kohtaan kehittyivät myönteisemmiksi. (Mattila-Wiro \& Tiainen 2019, 11-13.)

Vaikka osatyökykyisten mahdollisuutta työn tekemiseen on pidetty tärkeänä ja sitä on pyritty edistämään, vaatii tämä edelleen toimia (Oivo \& Kerätär 2018, 9-10). Nykyiset työllisyyttä edistävät ja aktiivisuutta lisäävät toimet eivät aina auta, vaan ne voivat jopa heikentää hyvinvointia ja henkilöiden osallisuus kutistuu osallistumiseksi (Mäntyneva 2020). Työelämä tarvitsee uudenlaisia palveluita, joissa erityisesti osallisuuden ja toimijuuden vahvistuminen on huomioitu. Tässä käytäntökuvauksessa esitellään Puuttuva pala -hankkeessa kehitetty Tuetun keikkatyön malli, jossa on kiinnitetty erityistä huomiota juuri osatyökykyisten osallisuuden ja toimijuuden vahvistumiseen. 


\section{Yhteiskehittelyn tuloksena Tuetun keikkatyön malli}

Puuttuva pala -hankkeen toteuttajina ovat Metropolia Ammattikorkeakoulu ja Etelä-Suomen Klubitalo ESKOT ry ja rahoittajana Euroopan sosiaalirahasto ja STEA. Tavoitteena on muodostaa osatyökykyisille ja heikossa työmarkkina-asemassa oleville työllistymisen polkua tuetun työllistymisen ja avoimien työmarkkinoiden välille. Hankkeessa on luotu Tuetun keikkatyön malli ja kokeiltu tuettua keikkatyötä käytännössä. Keikkatyöllä tarkoitetaan lyhyitä, usein yhden tai muutaman kerran työkertoja. Keikkatyö liittyy usein työpaikan ruuhkiin tai urakkatilanteisiin, joissa tarvitaan lisätyöntekijöitä. Tuetun keikkatyön on todettu sopivan erityisesti silloin, kun henkilöllä on halua päästä työelämään, kokeilla ja etsiä itselleen sopivaa työtä ja kun hänellä on halua saada lisää tietoa omasta työkyvystään. Moni työhön haluava miettii elämäntilannettaan ja sitä, miten se sallii työntekemisen. Keikkatyön etuna on mahdollisuus vaihdella tehtyjen työkeikkojen määrää oman voinnin mukaan. Myös mahdollisuus erilaisten työtehtävien kokeiluun voi tuntua turvalliselta, mikäli kokemusta omaan tilanteeseen sopivista työtehtävistä ei ole.

Tuetun keikkatyön mallia on kehitetty yhteiskehittelyn menetelmin. Kehittämistyössä on ollut mukana laaja joukko toimijoita. Keskeisiä osallistujia ovat olleet keikkatyöstä kiinnostuneet osatyökykyiset sekä työvalmentajat, jotka tarjoavat tukea keikalle haluavalle henkilölle ja keikkatyötä tarjoavalle työpaikalle. Mukana on ollut myös esimerkiksi järjestöjen ja yritysten edustajia ja kaupunkien toimijoita. Tavoitteena tuetussa keikkatyössä on löytää sellainen työpaikka ja -tehtävä, joka vastaa työntekijän tavoitteisiin, voimavaroihin ja työkykyyn. Tuetun keikkatyön prosessi käynnistyy, kun henkilöllä herää ajatus, että hän haluaisi työkeikalle, ja hän kertoo siitä työvalmentajalle. He tekevät yhdessä alkukartoituksen, jossa tarkastellaan henkilön kokonaiselämäntilannetta ja asioita, jotka kiinnostavat tai mietityttävät häntä keikkatyössä. Työvalmentaja arvioi yhdessä keikkatyöhön haluavan kanssa, onko juuri nyt oikea hetki keikkatyölle.

Keikkatyöhön haluava voi osallistua Kohti keikkaa -ryhmään, jossa tarkastellaan omaa hyvinvointia, työhön liittyviä toiveita ja jännityksiä sekä sitä, minkälaista tukea työelämään kaipaa. Ryhmässä myös mietitään, mitä keikkatyö on, millaisia vaatimuksia siihen liittyy ja miten se soveltuu omaan tilanteeseen. Keskusteluiden lisäksi ryhmässä hyödynnetään esimerkiksi Työterveyslaitoksella kehitettyä työ- ja toimintakyvyn itsearviointivälinettä Kykyviisaria, jossa arvioidaan omaa kokonaistilan- 
netta, vahvuuksia ja kehittämiskohteita. Keikkatyön etsimiseen valmistaudutaan osaamisen ja taitojen kartoittamisen lisäksi ansioluettelon ja oman työntekijäkuvauksen tekemisellä. Kohti keikkatyötä -ryhmässä tutustutaan työvälitysalustaan tai työnhakupalveluun ja harjoitellaan niiden käyttöä. Mikäli ryhmä ei sovellu henkilön tarpeisiin tai tilanteeseen, voi hän täyttää itsenäisesti työkirjaa, jossa keskitytään esimerkiksi omiin vahvuuksiin, ennakoidaan keikalle menemistä ja mietitään, miten kertoa itsestä työnantajalle.

Keikkatyöhön haluavan henkilön kanssa tehdään myös sosiaaliturvaselvitys, jonka tarkoituksena on selventää, miten palkkatulo vaikuttaa sosiaaliturvaan. Sosiaaliturvaan liittyvät kysymykset ovat usein monimutkaisia ja vaikeasti selvitettäviä, ja pelko etuuksien takaisinmaksusta, viivästyneestä etuudesta tai paperisodasta voivat estää työn vastaanottamisen (Kurvinen, Jolkkonen, Lemponen \& Ylhäinen 2019; Oivo \& Kerätär 2018, 61). Yhdessä työvalmentajan kanssa tehdyllä selvityksellä epävarmuus ja myöhemmät taloudelliset kompastuskivet voidaan välttää.

Keikkatyön käytännön järjestelyissä on hyödynnetty työnvälitykseen kehitettyä sähköistä alustaa, johon keikkatyöhön haluava kirjaa kuvauksen itsestään ja jossa myös sovitaan työtehtävästä, sen kestosta ja siitä maksettavasta palkkiosta. Työvalmentaja tukee sopivan keikkatyön etsimisessä. Sen lisäksi, että keikkatyötä etsitään työnvälitysalustoilta, työvalmentaja etsii keikkatyöläisten palkkaamisesta kiinnostuneita työpaikkoja, kertoo heille tuetun keikkatyön mallista ja etsii yhdessä keikkatyöhön haluavan kanssa tarjolla olevista keikkatöistä sopivan.

Kun sopiva keikkatyö löytyy, käy keikalle lähtevä työntekijä yhdessä työvalmentajan kanssa läpi työtehtävät ja -ohjeet, mikäli sellaisia on olemassa. He käsittelevät yhdessä myös muita keikalle lähtemiseen liittyviä asioita, kuten työmatkaa, ohjeiden ja neuvojen kysymistä sekä työyhteisön huomioimista. Keikalle lähtevän työntekijän lisäksi työvalmentaja tarjoaa tietoa ja tukea myös työpaikalle ja varmistaa esimerkiksi, että keikkatyöhön tulija perehdytetään tehtäviin. Hän myös varmistaa, että keikkatyöhön tulijalla ja työpaikalla on yhteiset näkemykset työtehtävistä ja -tavoista. Työvalmentajan tarjoamaan tukeen sisältyy myös esimerkiksi keikkatyön vaativuuden arviointia ja työohjeiden selkeyttämistä. Työvalmentaja on tarvittaessa läsnä myös keikkatyötä tehtäessä. Osatyökykyisten palkkaamisessa juuri riittävä tuki, konkreettinen apu ja työvalmentajan saatavilla oleminen ovat sekä työntekijän että työnantajan kannalta merkityksellisiä ja palkkaamisen mahdollistavia tekijöitä (Åkerblad \& Haapakoski 2020). 
Keikan lopuksi työntekijä käy läpi yhdessä työvalmentajan kanssa, miten työkeikka sujui. Tähän vaiheeseen kuuluvat myös palautteen antaminen työnantajalle ja työkeikan tekijälle. Palautteen antaminen tapahtuu samalla sähköisellä alustalla, jolla työkeikasta on alun perin sovittu. Keikan jälkeen työntekijä käy työvalmentajan kanssa läpi opitut asiat ja sen, mitä vahvuuksia ja osaamista tehtävään liittyi. Lisäksi työntekijä miettii yhdessä työvalmentajan kanssa, mitä työntekijä toivoo tulevaisuudelta: olisiko se uusi työkeikka vai jokin muu toiminta, esimerkiksi koulutukseen hakeutuminen. On myös mahdollista, että keikkatyön myötä työntekijälle syntyy kokemus siitä, ettei työskentely ole sillä hetkellä ajankohtaista. Kun arviointi työkyvystä tapahtuu todellisessa työtilanteessa, on se konkreettisempi ja realistisempi kuin yksinomaan lomakkeiden ääressä tehty pohdinta.

\section{Tuuliajolta oman elämän ohjaajaksi}

Yksi tuetun keikkatyön tärkeistä puolista on se, että työntekijälle maksetaan työehtosopimuksen mukaista palkkaa. Monelle osatyökykyiselle huoli taloudellisesta tilanteesta on arkipäivää, mikä voi kaventaa elämää ja johtaa kadottamaan mahdollisuuden tarkastella tulevaisuutta (ks. esim. Nivala \& Ryynänen 2019, 171). Tulot eivät kuitenkaan ole tuetun keikkatyön ainoa lisäarvo. Esimerkiksi tuettua keikkatyötä tehnyt nimimerkki Jaaju on blogitekstissään todennut "En ole tuuliajolla" (Puuttuva pala -hankkeen blogi 2021). Lauseeseen tiivistyy nimimerkin kokemus siitä, että tuettu keikkatyö on tuonut mukanaan suuntaa elämään.

Palkkatyöllä on Suomessa merkittävä asema normaaliuden rakentajana, mikä saa aikaan sen, että työn ulkopuolella oleva voi määrittyä yhteiskuntaan sopimattomaksi (Gould \& Kaliva 2010; Nivala 2008, 263). Tämä voi ilmetä yksilölle kokemuksena siitä, ettei ole mitään mihin kiinnittyä, jolloin päätyy seilaamaan työelämän lisäksi yhteiskunnan ja yhteisön ulkopuolella. Työmarkkinoiden ulkopuolella olemiseen liittyy usein sosiaalisten kontaktien väheneminen ja arjen rakenteiden katoaminen. $\mathrm{Ne}$ voivat yhdistyä häpeän ja arvottomuuden kokemuksiin, jotka syventävät ulkopuolisuuden kokemusta. (Hirvilammi \& Mäki 2013; Hult, Saaranen \& Pietilä 2016; Vilppola 2021.)

Nimimerkki Jaaju kirjoittaa blogitekstissään saaneensa tuetun keikkatyön myötä elämäänsä lisää vastuuta. Lisäksi hän kertoo kokeneensa, että häneen luotetaan ja että hänellä on taitoja ja osaamista erilaisiin tehtäviin. Onnistuneen tuetun keikkatyön myötä syntyneet hyvät kokemukset tuo- 
vat omat kyvyt ja osaamisen näkyviksi. Kun tuetun keikan myötä kertyy ymmärrystä käytössä olevasta työelämän toimintakyvystä, on sillä yhteys myös toimijuuden vahvistumiseen.

Yhtenä keskeisenä tekijänä toimijuuden vahvistumisessa on se, että tuetun keikkatyön malli nojautuu voimakkaasti henkilön omiin valintoihin ja vapauteen toimia. Keikkatyöhön ei liity ulkopuolelta tulevaa pakotettua aktiivisuutta ja toimijuutta, vaan sen lähtökohdat ovat yksilön omissa tavoitteissa ja toiveissa (ks. esim. Isola ym. 2017, 25-26; Nivala \& Ryynänen 2019, 105). Tämä periaate on läsnä prosessin alusta pitäen, koska tuettuun keikkatyöhön lähteminen perustuu henkilön omaan toiveeseen. Tuetun keikkatyön aikana tavoitteena on työntekijän oman potentiaalin kokonaisvaltainen tukeminen ja näkyväksi tekeminen. Tuetusta keikkatyöstä kiinnostunut henkilö on vahvasti oman elämänsä subjekti sen sijaan, että hänet asetettaisiin toiminnan kohteeksi. Hänellä nähdään olevan keskeinen tieto omasta historiastaan ja vahvuuksistaan. Tuetun keikkatyön prosessin avulla pyritään lisäämään hänen uskoaan ja luottamustaan oman toimijuutensa kannattelukykyyn. Mahdollisuudet vaikuttaa omaan elämään ja toimintoihin vahvistavat myös kokemusta osallisuudesta omaan elämään (Isola ym. 2017, 25).

Toimijuuden vahvistumisen prosessissa omien havaintojen lisäksi myös muiden osoittama luottamus ja antama palaute ovat merkittävässä asemassa (Leeman ym. 2018, 13; Nivala \& Ryynänen 2019, 95). Joskus omat onnistumiset voivat jäädä tuetun keikkatyön tekijältä huomaamatta, minkä vuoksi palautteen saaminen työnantajalta ja työvalmentajalta on tärkeää. Yhteisen keskustelun kautta usko itseen vahvistuu, ja samalla tulevaisuuden näkymät ja tavoitteet voivat selkiytyä. Työvalmentajalla on merkittävä rooli keskustelukumppanina ja peilinä koko prosessin ajan. Räätälöidyn ja yksilöidyn tuen ja palveluiden on todettu olevan se, mitä osatyökykyisten palveluissa tarvitaan yleisten, kaikille yhtenäisten palveluiden sijaan (Juvonen-Posti, Saikku \& Turunen 2020, 234-235).

Kohti keikkaa -ryhmään osallistuminen mahdollistaa osatyökykyiselle omaan itseen liittyvien pohdintojen lisäksi muiden keikkatyöstä kiinnostuneiden kokemuksien ja pohdintojen kuulemisen. Henkilökohtaisen prosessin rinnalla kulkee yhteinen prosessi, jossa jaetaan ajatuksia ja jossa on mahdollista oppia yhdessä. Vain lyhyenkin ajan kokoontuva ryhmä voi tarjota tilan kokemusten vaihtamiselle ja erilaisten vaihtoehtojen pohtimiselle. Ryhmä mahdollistaa yhteisen voimistuvan toimijuuden muodostumisen (Isola ym. 2017, 27). Yhteisen asian ääreen pysähtyminen tuottaa 
yhteenkuuluvuuden tunnetta, merkityksellisiä kohtaamisia ja osallisuuden kokemuksen (ks. myös Nivala \& Ryynänen 2019, 119-121; Vilppola 2021, 81).

Keikkatyöhön valmentavien ryhmien lisäksi myös työpaikoilla tehty työ on tarjonnut osatyökykyisille yhteyksiä muihin ihmisiin ja kokemuksia osana yhteisöä olemisesta. Tämä on osoitus siitä, että lyhyidenkin työkeikkojen kautta on mahdollista kokea johonkin kuulumista ja yhteyttä muihin ihmisiin. Tasa-arvoiset kohtaamiset ja kokemus hyväksytyksi tulemisesta tuovat merkityksellisyyttä elämään (Hedman ym. 2021). Tällaiset vuorovaikutussuhteet, jotka lisäävät merkityksellisyyden, tarpeellisuuden ja luottamuksen kokemuksia, ovat osallisuuden edellytyksiä ja mahdollistajia (Isola \& Siukola 2017; Leeman ym. 2018, 13). Monelle tuetusta keikkatyöstä kiinnostuneelle merkityksellistä on myös se, että voi kokea olevansa hyödyksi ja työn kautta osallisena yhteiskunnan pyörittämisessä. Lisäksi työkeikan arvoa nostaa se, että työtehtävä on sellainen, johon todella tarvitaan tekijä ja josta maksetaan asianmukainen korvaus. (Ks. myös Nivala \& Ryynänen 2019, 160-161, Vilppola 2021, 167.)

Aina tuettuun keikkatyöhön valmentautuminen ei johda työhön tai työkeikka ei ole yksinomaan myönteinen kokemus. Myös näissä tilanteissa työvalmentajan kanssa käydyillä keskusteluilla on merkitystä. Mikäli käy niin, että työkeikka herättää epävarmuutta, on tärkeää käydä läpi, mihin se liittyi ja voiko haasteet ylittää esimerkiksi varmistamalla, että seuraavalla työkeikalla työohjeet ovat riittävät. Keskustelu voi aukaista myös ajatuksen siitä, ettei työnteon kokeilemisen aika ole juuri nyt, vaan osatyökykyisen on esimerkiksi tarpeen käyttää kaikki energiansa oman voinnin parantamiseen. Keskeistä on se, että henkilöllä itsellään on mahdollisuus käydä läpi vaihtoehtoja ja valita niistä itselleen ja omaan elämäntilanteeseensa parhaiten sopiva vaihtoehto. Oman elämän ratkaisujen tekeminen vahvistaa kokemusta siitä, että yksilö itse on elämänsä ohjaksissa sen sijaan, että joku toinen tai esimerkiksi yhteiskunnan rakenteet määräisivät suunnan. Toimijuus edellyttää luottamusta omien kykyjen lisäksi myös vaikutusmahdollisuuksiin (Nivala 2008, 175).

Tuetun keikkatyön mallin ajatuksena on, ettei toimijuuden vaade kohdistu yksinomaan keikkatyöhön haluavaan tai sitä tekevään henkilöön, vaan nähdään, että myös toimintaympäristöllä on merkitystä työn tekemisen mahdollisuuksille. Joissakin tilanteissa voidaan todeta, että tietynlaisissa työtehtävissä tuettua keikkatyötä tekevän osaaminen pääsee kukoistamaan ja hän jaksaa tehdä työtä, kun taas toisenlainen työympäristö 
vie voimat pitkäksi aikaa. Keskeistä on löytää sopiva yhdistelmä, jossa henkilön kyvyt ja osaaminen sekä työpaikka muodostavat yhteensopivan parin.

\section{LÄHTEET}

Gould, R. \& Kaliva, K. 2010. Työkyvyttömyyseläke ja ansiotyö. Eläketurvakeskuksen raportteja 2010: 5. Helsinki: Eläketurvakeskus.

Hedman, L., Ikonen, J., Leemann, L., Koskela, T., Martelin, T., Solin, P., Tamminen, N. \& Parikka, S. 2021. Osallisuuden kokemus ja positiivinen mielenterveys työmarkkinaaseman ja kotitalouden rakenteen mukaan - FinSote 2019 -tutkimuksen tuloksia. Helsinki: Terveyden ja hyvinvoinnin laitos. Saatavissa http://urn.fi/ URN:ISBN:978-952-343-624-4 (haettu 24.5.2021).

Hirvilammi, T. \& Mäki, S. 2013 Toimeentulovaikeuksia, yksinäisyyttä ja alemmuuden kokemuksia. Perusturvan saajien rajalliset toimintamahdollisuudet. Teoksessa O. Kangas, M. Niemelä \& A. Raijas (toim.) Takaisin perusteisiin. Perusturvan riittävyys kulutuksen näkökulmasta. Tampere: Kelan tutkimusosasto, 120-141.

Hult, M., Saaranen, T. \& Pietilä, A.-M. 2016. Työttömien kokemuksia terveydestä ja hyvinvoinnista: haastattelututkimus. Sosiaalilääketieteellinen Aikakauslehti 53 (2), 108-118. Saatavissa https://journal.fi/sla/article/view/56917 (haettu 24.5.2021).

Isola, A.-M. \& Siukola, R. 2017. Arvottomat? Köyhien naisten ja miesten kokemuksia arvokkuudesta suomalaisessa hyvinvointivaltiossa. Teoksessa S. Hänninen \& P. Saikkonen (toim.) Hyvinvointivaltio ylittää jälkensä. Helsinki: Terveyden ja hyvinvoinnin laitos, 111-128.

Isola, A.-M., Kaartinen, H., Leemann, L., Lääperi, R., Schneider, T., Valtari, S. \& Keto-Tokoi, A. 2017. Mitä osallisuus on? Osallisuuden viitekehystä rakentamassa. Helsinki: Terveyden ja hyvinvoinnin laitos. Saatavissa http://urn.fi/ URN:ISBN:978-952-302-917-0 (haettu 24.5.2021).

Juvonen-Posti, P., Saikku, P. \& Turunen, J. (toim.). 2020. Elinikäistä osallistumista vai elämää työ edellä? Työikäisten monialaisten palveluiden yhteensovittaminen ja vaikuttavuuden arviointi -loppuraportti. Valtioneuvoston selvitys- ja tutkimustoiminnan julkaisusarja 2020:40. Helsinki: Valtioneuvosto. Saatavissa https:// julkaisut.valtioneuvosto.fi/bitstream/handle/10024/162412/VNTEAS_2020_40.pdf (haettu 24.5.2021).

Kurvinen, A., Jolkkonen, A., Lemponen, V. \& Ylhäinen, M. 2019. Pitkäaikaistyöttömissä on työvoimapotentiaalia. Työ- ja elinkeinoministeriön julkaisuja 2019:12. Helsinki: Työ- ja elinkeinoministeriö.

Leemann, L., Isola, A.-M., Kukkonen, M., Puromäki, H., Valtari, S. \& Keto-Tokoi, A. 2018. Työelämän ulkopuolella olevien osallisuus ja hyvinvointi. Kyselytutkimuksen tuloksia. Helsinki: Terveyden ja hyvinvoinnin laitos. 
Mattila-Wiro, P. \& Tiainen, R. 2019. Kaikki mukaan työelämään. Osatyökykyisille tie työelämään (OTE) kärkihankkeen tulokset ja suositukset. Sosiaali- ja terveysministeriön raportteja ja muistioita 2019:25. Helsinki: Sosiaali- ja terveysministeriö.

Mäntyneva, P. 2020. Lektio praecursoria. Sosiaalipedagoginen aikakauskirja 21, 153-160. DOI: https://doi.org/10.30675/sa.101291.

Nivala, E. 2008. Kansalaiskasvatus globaalin ajan hyvinvointiyhteiskunnassa. Kansalaiskasvatuksen sosiaalipedagoginen teoriakehys. Kuopio: Snellman-instituutti.

Nivala, E. \& Ryynänen, S. 2019. Sosiaalipedagogiikka. Kohti inhimillisempää yhteiskuntaa. Helsinki: Gaudeamus.

Oivo, T. \& Kerätär, R. 2018. Osatyökykyisten reitit työllisyyteen - etuudet, palvelut, tukitoimet. Sosiaali- ja terveysministeriön raportteja ja muistioita 43/2018. Helsinki: Sosiaali- ja terveysministeriö.

Puuttuva pala -hankkeen blogi 25.3.2021. Saatavissa https://puuttuvapala.metropolia.fi/ blogi/keikkalaisen-puheenvuoro-keikkatyo-kriisiaikana/ (haettu 24.5.2021).

Vilppola, J. 2021. Toimijat, taistelijat, tipahtaneet. Koulutus- ja työtoimijuus mielenterveyskuntoutujien elämänkerronnoissa. Turku: Turun yliopisto.

Åkerblad, L. \& Haapakoski, K. 2020. Työnantajayhteistyö ammatillisessa kuntoutuksessa ja tuetussa työllistymisessä. Integroiva kirjallisuuskatsaus. Kuntoutus 43 (3), 20-33. DOI: https://doi.org/10.37451/kuntoutus.100140. 
220 - Sosiaalipedagoginen aikakauskirja, vuosikirja 2021, vol. 22 